\title{
Some Aspects of Biology of Chola Punti Puntius Chola (Hamilton) from the Kangsa River
}

\author{
Bi. K. Saha and A. Saha \\ Department of Zoology, Netrakona Govt. College, Netrakona, Bangladesh.
}

\begin{abstract}
The mean values of total length (75.89 $\pm 13.09 \mathrm{~mm})$, standard length (54.98 $\pm 7.07 \mathrm{~mm})$, fork length (60.86 $\pm 9.14 \mathrm{~mm})$, head length $(14.75$ $\pm 2.05 \mathrm{~mm}$ ), snout length (3.79 $\pm 0.61 \mathrm{~mm})$, pre-dorsal length (31.53 $\pm 3.18 \mathrm{~mm})$, height of body $(20.2 \pm 4.11 \mathrm{~mm})$ and total weight $(6.62$ $\pm 3.55 \mathrm{~g}$ ) of combined sex of Puntius chola were calculated. Relationships between total length and standard length, fork length, head length, snout length and pre-dorsal length of Puntius chola were found to be linear, positive and highly significant. The length-weight relationship in male, female and combined sex were determined as Log W =-4.510+2.810 Log L, LogW=-4.204+2.685 Log L and Log W=4.465+2.808 $\log \mathrm{L}$ respectively. The mean values of condition factor from observed value (ko) of male, female and combined sex were determined as $1.36 \pm 0.089,1.599 \pm 0.181$ and $1.515 \pm 0.192$ respectively. The mean values of condition factor from calculated value (kc) of male, female and combined sex were found to be $1.362 \pm 0.054,1.6 \pm 0.124$ and $1.511 \pm 0.075$ respectively. The mean values of relative condition factor of male, female and combined sex were registered as $0.999 \pm 0.044,0.999 \pm 0.064$ and $0.999 \pm 0.112$ respectively. Sex ratio was found to be $1: 1$.
\end{abstract}

Key words: Standard length, Pre-dorsal length, Puntius chola, Morphomertric, Fish culture.

\section{Introduction}

Among the barbs (Family Cyprinidae), Puntius (Hamilton) is one of the most common and abundant individuals in the fish fauna of Bangladesh. Puntius chola is the most common species which widely occurs in rivers, canals, beels, haors, ponds and inundated fields throughout Bangladesh. It is also distributed in the freshwaters of India, Pakistan, Burma, Nepal and Srilanka (Talwar and Jhingran 1991). In Burma, it is reported to be rich in fat during the breeding season and oil is extracted from it (Talwar and Jhingran 1991). It can be a good aquarium fish. The purpose of the length-weight analysis is to describe mathematical relationship between length and weight, primarily so that one may be converted into other and of condition factors to measure the variation from the expected weight for length of individual fish or groups of fishes as indication of relative robustness, plumpness or fatness, degree of well-being etc (Le Cren 1951).

The object of the present investigation is to find out some aspects of biology viz. morphometrics, length-weight relationship, condition and sex ratio of chola punti (Puntius chola ) from the Kangsa river habitat that may have practical value in culture, management and further development of fishery relating to this fish in Bangladesh.

\section{Materials and Methods}

A total of 198 specimens of $P$. chola was collected once a month by cast nets and and drag nets during January to December 2006 from the Kangsa river fishing ground of Netrakona district. After collection, the fishes were preserved in 5\% formalin. The fishes were measured in the nearest mm by means of a measuring board fitted with a centimeter scale and their weights were recorded by means of a sensitive pan balance. Statistical formulae given by Snedecor 1956 and Simpson et al. 1960 were used to establish mathematical relationship between total length and other variables.

Different lengths and weights of chola punti specimens were recorded in mm and g respectively. The TL and TW relationship of these fishes were determined by using the logarithmic transformation of the well known formula : $\mathrm{W}=a L^{\mathrm{n}}$ (Le Cren 1951), where $W=$ weight, $L=$ length, a is a constant and an exponent. Values for a and n were found empirically.

The value of the co-efficient of condition $(\mathrm{k})$ is calculated from the cube law equation $\mathrm{W}=\mathrm{KTL}^{3} \times 10^{5}$

\footnotetext{
* Corresponding author: E-mail:
} 
or

$$
\mathrm{K}=\frac{T W \times 10^{5}}{T L^{3}}
$$

Where $\mathrm{TW}=$ total weight, $\mathrm{TL}=$ total length, and $\mathrm{K}=$ the factor of proportion.

The fishes were differentiated into male and female after dissecting out the gonads.

\section{Results and Discussion}

\section{Morphometrics}

\section{Size frequency distribution}

The data on size frequency distribution of 198 individuals of P. chola are presented in Fig. 1. The specimens were grouped into 10 size groups of $6.0 \mathrm{~mm}$ class intervals. Minimum numbers of male fishes were observed in size group 92-98 $\mathrm{mm}$ while maximum numbers of male were found in 62-68 $\mathrm{mm}$ size group. Minimum numbers of female were found in 44-50 mm size group while maximum numbers of female were recorded in 74-80 mm size group. No females were recorded in 50-56 and 56-62 mm size groups. Rahman (1990) recorded the $70-75 \mathrm{~mm}$ size group of females Lepidocephalus guntea as dominant one for most of the months but in case of males, $70-75 \mathrm{~mm}$ size group dominated mostly and the next dominating group was $65-70 \mathrm{~mm}$ and 75-80 mm size groups.

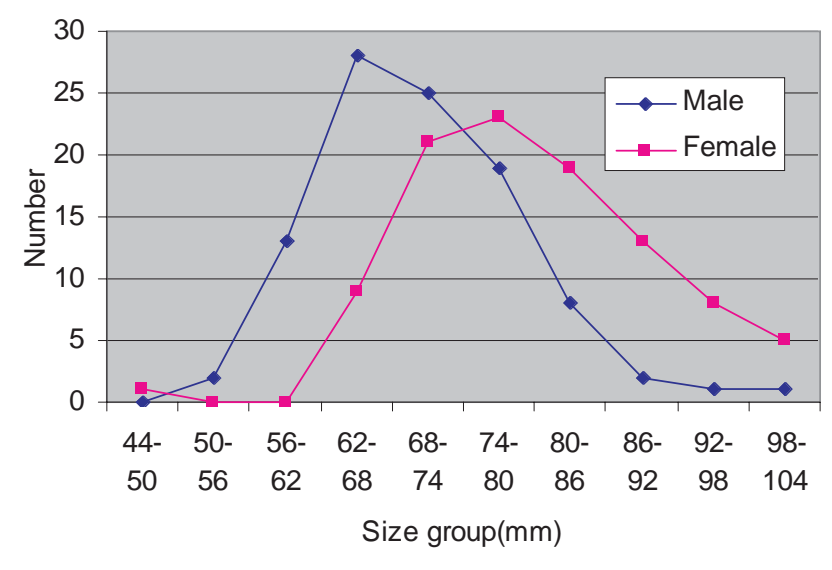

Fig. 1: Size frequency distribution of males and females of chola punti (Puntius chola) sampled from the Kangsa river

\section{Estimation of lengths}

The total length (TL) of the male specimens ranged from 52 $\mathrm{mm}$ to $98 \mathrm{~mm}$ with an average of $70.42 \pm 8.44 \mathrm{~mm}$; TL of the females from $44 \mathrm{~mm}$ to102 mm with mean of $80.85 \pm$ $10.4 \mathrm{~mm}$ and in combined sex of $P$. chola, the mean value was $75.89 \pm 13.09 \mathrm{~mm}$. The largest specimen reported so far measured $120 \mathrm{~mm}$ (Talwar and Jhingran 1991), $122 \mathrm{~mm}$ (Srivastava 1968), 125 mm (Shafi and Quddus 2001) and $138 \mathrm{~mm}$ (Rahman 1989). The standard length (SL) of the male fishes ranged from $39 \mathrm{~mm}$ to $75 \mathrm{~mm}$ with an average of $52.55 \pm 5.69 \mathrm{~mm}$; SL of the females ranged from $49 \mathrm{~mm}$ to $87 \mathrm{~mm}$ with an average of $57.02 \pm 4.79 \mathrm{~mm}$ and in combined sex i.e. male and female together , mean was $54.98 \pm$ $7.07 \mathrm{~mm}$. The fork length ( FL) of the male specimens varied from $46 \mathrm{~mm}$ to $75 \mathrm{~mm}$ with an average of $60.71 \pm 5.65$ $\mathrm{mm}$; FL of the females varied from $55 \mathrm{~mm}$ to $87 \mathrm{~mm}$ with a mean of $67.59 \pm 8.91 \mathrm{~mm}$ and in combined sex, mean recorded was $60.86 \pm 9.14 \mathrm{~mm}$. The head length (HL) of the male specimens varied from $12 \mathrm{~mm}$ to $20 \mathrm{~mm}$ with an average of $14.29 \pm 1.62 \mathrm{~mm}$; HL of the females varied from 13 $\mathrm{mm}$ to $23 \mathrm{~mm}$ with a mean of $16.05 \pm 2.56 \mathrm{~mm}$ and in combined sex, mean noted was $14.75 \pm 2.05 \mathrm{~mm}$. The pre-dorsal length (PDL) of the male specimens varied from $28 \mathrm{~mm}$ to $32 \mathrm{~mm}$ with an average of $30.00 \pm 1.29 \mathrm{~mm}$; PDL of the females varied from $26 \mathrm{~mm}$ to $39 \mathrm{~mm}$ having a mean of $32.55 \pm 3.62 \mathrm{~mm}$ and in combined sex, average was 31.53 $\pm 3.18 \mathrm{~mm}$. The snout length (SnL) of the male specimens varied from $3 \mathrm{~mm}$ to $4 \mathrm{~mm}$ with a mean of $3.57 \pm 0.49 \mathrm{~mm}$; $\mathrm{SnL}$ of the females varied from $3 \mathrm{~mm}$ to $6 \mathrm{~mm}$ having mean of $4.18 \pm 0.61 \mathrm{~mm}$ and in combined sex, mean was $3.79 \pm$ $0.61 \mathrm{~mm}$. The height of body (HB) of males ranged from 15 $\mathrm{mm}$ to $24 \mathrm{~mm}$ with a mean of $18.16 \pm 2.67 \mathrm{~mm}$; HB of females ranged from $16 \mathrm{~mm}$ to $30 \mathrm{~mm}$ with a mean of 23.3 $\pm 4.19 \mathrm{~mm}$ and in combined sex, the mean being $20.2 \pm 4.11$ $\mathrm{mm}$.

The total weight of the male specimens ranged from $1.75 \mathrm{~g}$ to $12.5 \mathrm{~g}$ with a mean of $4.93 \pm 2.07 \mathrm{~g}$. In females, it ranged from $2.1 \mathrm{~g}$ to $19.5 \mathrm{~g}$ with a mean of $8.28 \pm 3.54 \mathrm{~g}$ and in combined sex, the average was $6.62 \pm 3.35 \mathrm{~g}$.

\section{Total length and standard length}

Scattered diagram (Fig.2) of total length and standard length suggests a linear, positive and most highly significant relationship between them. From the regression analysis of standard length $(\mathrm{Y})$ on total length $(\mathrm{x})$, the following equation was obtained :

$$
Y=0.805 \times-2.356
$$


Rahman (1990) determined the relationship between total length and standard length of $L$. guntea as highly significant $(r=0.999)$.

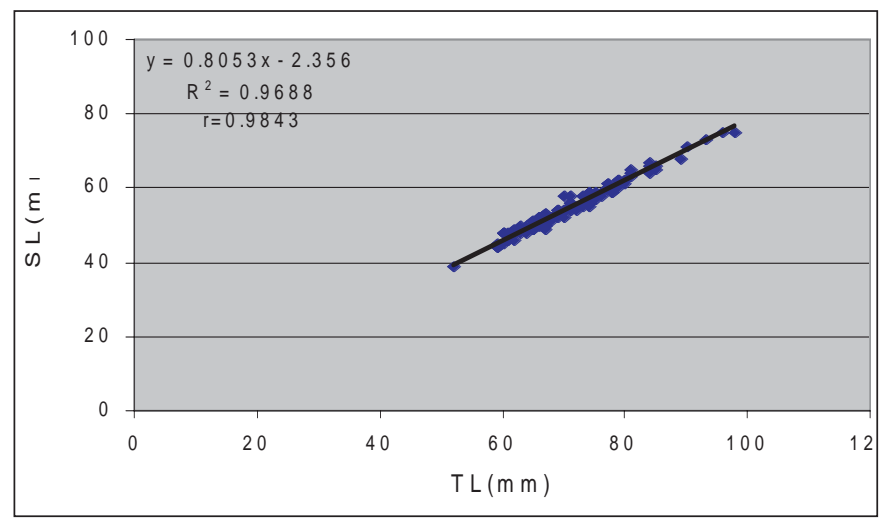

Fig. 2: Relationship between Total Length (TL)(mm) and Standard Length (SL) (mm) of chola punti (Puntius chola)

\section{Total length and fork length}

Scattered diagram of total length and fork length clearly suggests a linear relationship between them. The relation is positive and most highly significant. The equation estimated from the regression analysis was as follows :

$$
\mathrm{Y}=0.898 \times-0.806
$$

\section{Total length and head length}

Scattered diagram of total length and head length clearly proposes a linear, positive and significant relationship between them. The equation derived from the regression analysis was established as follows:

$$
\mathrm{Y}=0.182 \times-2.076
$$

\section{Total length and snout length}

Scattered diagram (Fig. 3) of total length and snout length shows a linear relationship between them. The relation is positive and highly significant. The following equation was calculated:

$$
Y=0.053 \times-0.086
$$

\section{Total length and pre-dorsal length}

Scattered diagram of total length and pre-dorsal length depicts a linear, positive and most highly significant relationship between them. From the regression analysis of standard length $(\mathrm{Y})$ on total length $(\mathrm{X})$, the equation was established as follows :

$$
\mathrm{Y}=0.380 \times+0.880
$$

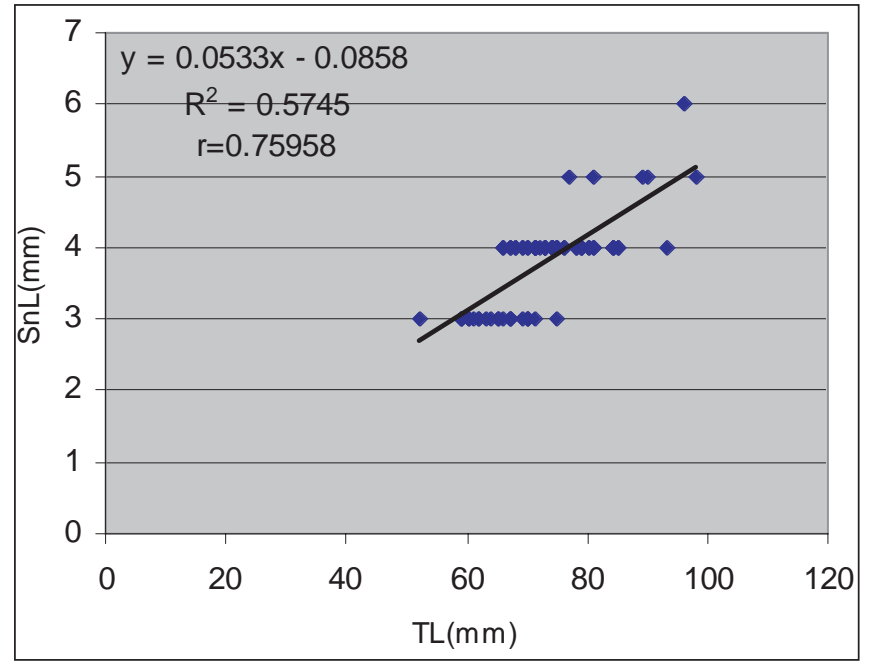

Fig. 3 : Relationship between Total Length (TL)(mm) and Snout Length (SnL) (mm) of chola punti (Puntius chola)

\section{Length-weight relationship}

The length-weight relationship for the individuals of P.chola ranging in size from 44.0 to $102.0 \mathrm{~mm}$ and weight from 1.75 to $19.5 \mathrm{~g}$ was estimated. The Total length -Weight relationship in male P.chola was determined as Log W $=-4.510+$ $2.810 \log \mathrm{L}$ (Fig. 4a). In case of female, the relationship was determined as $\log W=-4.204+2.685$ Log L (Fig. 4b) and in combined sex, the relationship was determined as Log $\mathrm{W}=4.465+2.808 \mathrm{Log} \mathrm{L}$ (Fig. 4c ). It is observed from the Figs. 4a, 4b and 4c that the weight bears a curvi-eslinear relationship with the total length. Doha (1974) obtained the equation from the length-weight relationship of Glossogobius giuris as Log $\mathrm{W}=-4.657+2.816$ LogL from Mymensingh water. According to Shafi and Quddus (1975), the equation from the length-weight relationship of Labeo rohita from the river water was Log $\mathrm{W}=-2.445-3.322 \log \mathrm{TL}$.

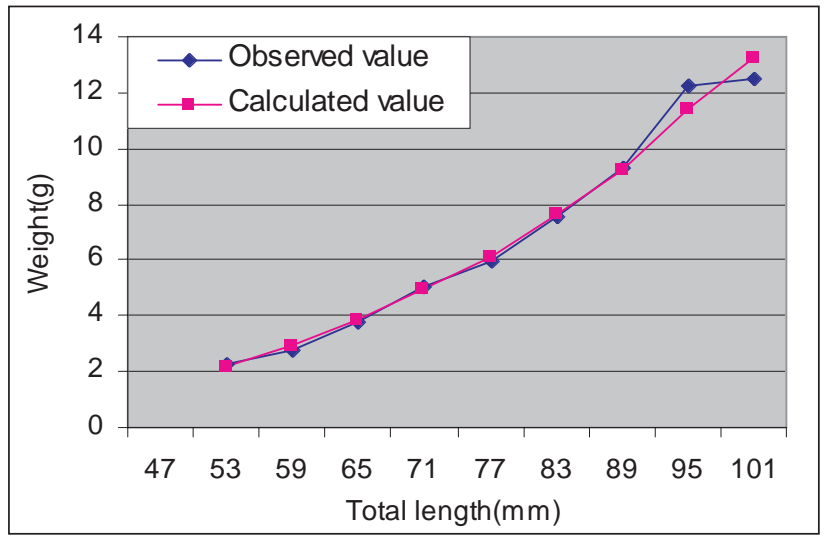

Fig. 4a: Relationship between total length (TL) and total weight (TW) in male P.chola. 


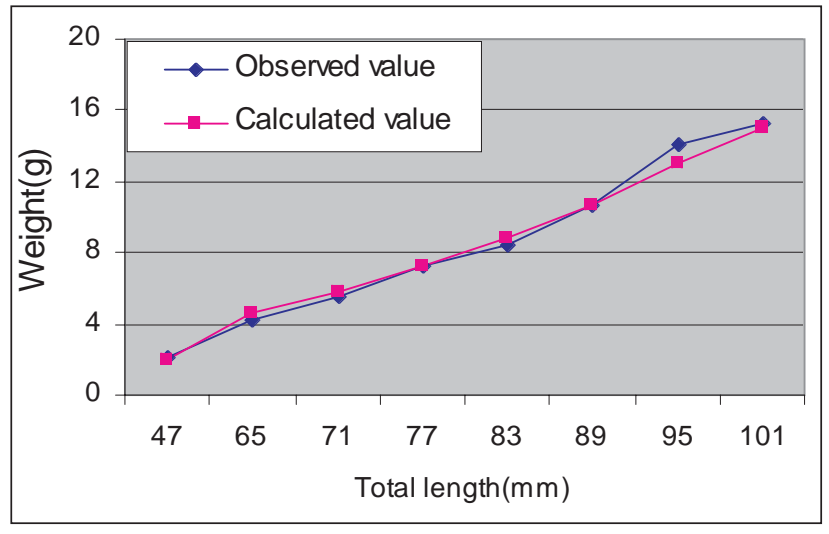

Fig. 4b: Relationship between total length (TL) and total weight (TW) in female P.chola

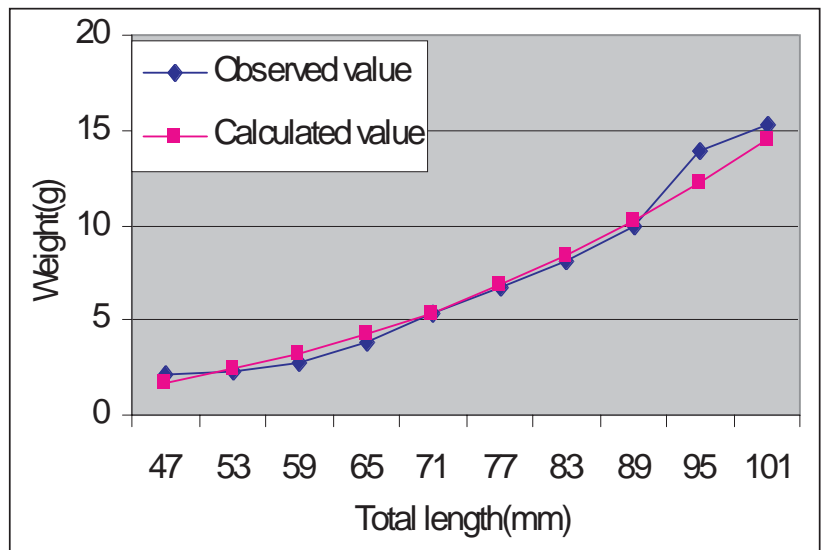

Fig. 4c: Relationship between total length (TL) and total weight (TW) in combined sexes of P.chola

\section{Condition factor}

\section{Condition factor from observed value (Ko)}

In male $P$. chola, the value of ko ranged from 1.213 to 1.528 with a mean value of $1.36 \pm 0.089$ (Fig 5a ). For the female $P$. chola, the mean values of ko was obtained as $1.599 \pm$ 0.181 with a range of 1.478 to 2.023 (Fig 5b ). For the combined sex of $P$. chola, the value of ko varied from 1.361 to 2.023 with a mean of $1.515 \pm 0.192$ (Fig. 5c). From the observation of Rahman (1990), the mean values of ko for the males, females and combined sexes of $L$. guntea were $0.821,0.87$ and 0.856 respectively.

\section{Condition factor from calculated value (kc)}

The male P. chola showed a mean ' $\mathrm{k}$ ' as $1.362 \pm 0.054$ and the range 1.282 to 1.450 ( Fig $5 a$ ). In case of female, the values ranged from 1.457 to 1.856 with a mean value of $1.6 \pm$
0.124 (Fig. 5b). The combined sex showed the value of ' $k$ ' as 1.414 to 1.638 with a mean value of $1.511 \pm 0.075$ (Fig. 5c). According to Rahman (1990), the mean values of kc are 0.822, 0.869 and 0.856 for the male, female and combined sexes of $L$. guntea respectively.

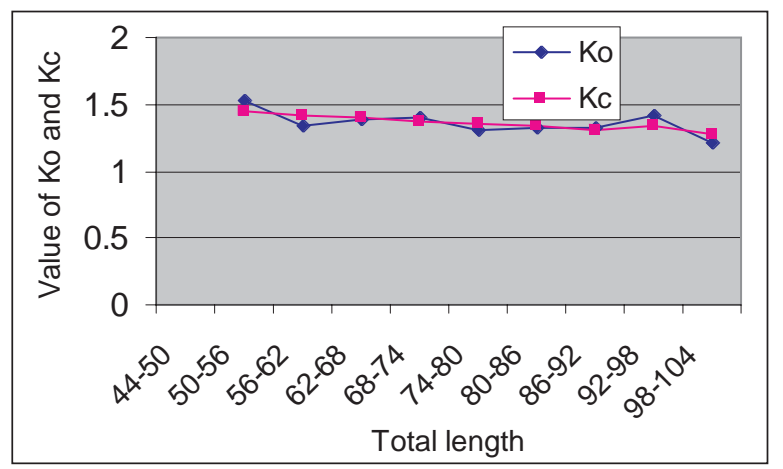

Fig. 5a: Relationship between total length (TL) and condition factor for observed weight ( Ko) and calculated weight $(\mathrm{Kc})$ in male punti (Puntius chola)

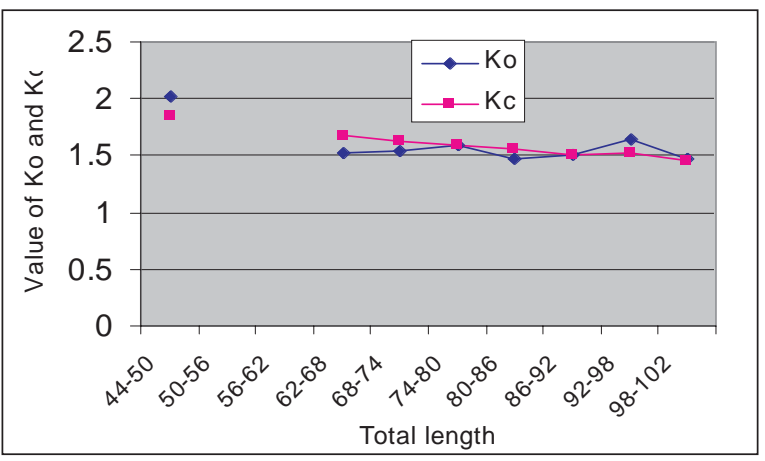

Fig. 5b: Relationship between total length (TL) and condition factor for observed weight (Ko) and calculated weight (Kc) in female punti (Puntius chola)

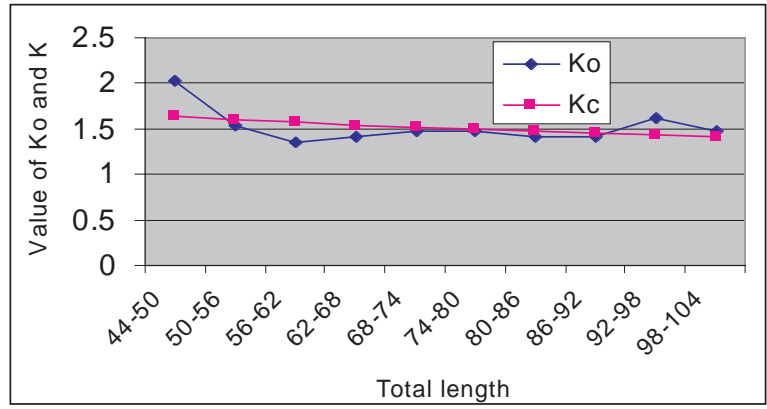

Fig. 5c: Relationship between total length (TL) and condition factor for observed weight (Ko) and calculated weight $(\mathrm{Kc})$ in combined sexes of punti (Puntius chola) 


\section{Relative condition factor}

The kn values of male $P$. chola ranged from 0.940 to 1.068 with a mean value of $0.999 \pm 0.044$ ). In case of female, the $\mathrm{kn}$ values varied from 0.905 to 1.090 with a mean value of $0.999 \pm 0.064$. In combined sex, the kn values varied from 0.868 to 1.235 with an average value of $0.999 \pm 0.112$ (Fig. 6). From the observation of Shafi and Quddus (1975), the relative condition factor was found to be highest for the earliest size groups of Labeo rohita from the river water and fluctuations in the relative condition in fishes of length ranged from $45 \mathrm{~cm}$ to $70 \mathrm{~cm}$ appeared to be more or less similar. Rahman (1990) observed the relative condition factors of L. guntea as 1.001, 1.004 and 1.0 in male, female and combined sexes respectively.

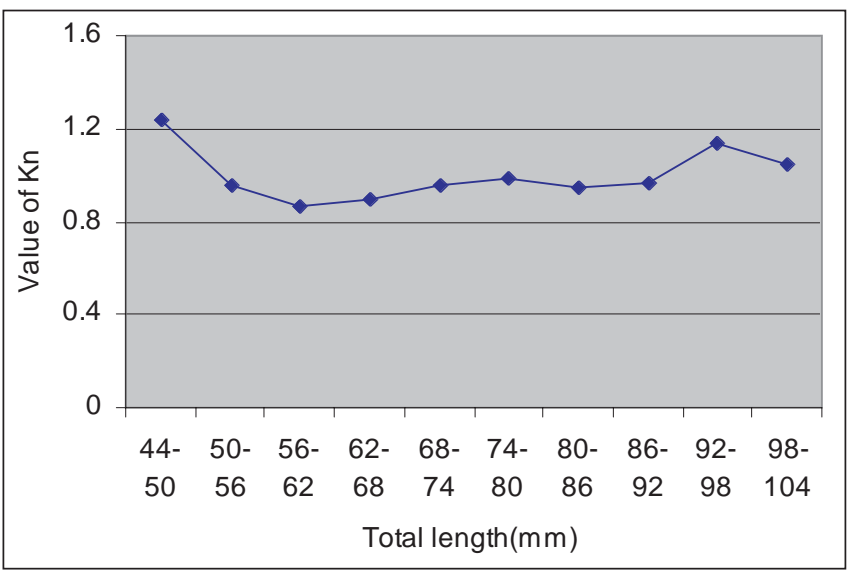

Fig. 6: Relationship between total length (TL) and relativecondition factor $(\mathrm{Kn})$ in combined sexes of punti (Puntius chola)

\section{Sex ratio}

\section{Sexual dimorphism}

The species was sexed on the basis of body colour. The sexes were distinguished by the presence of orange-tinted colour on anal and pelvic fins of the male. All the fins of the females were quite clear. During the breeding season, the males developed a red band along the side from the end of opercle to the forked end of caudal fin (Rahman 1990, and Shafi and Quddus 2001).

\section{Sex ratio}

Out of 198 individuals of $P$. chola, 99 were male and 99 were female. The male to female ratio i.e. sex ratio was found to be 1:1. The monthwise male and female ratios are shown in
Fig.7. It is obvious from the Fig.7. That the dominance of one sex throughout the year was not determined. Latifa and Nahar (1987) observed the sex ratio of $P$. stigma as $1: 1.5$.

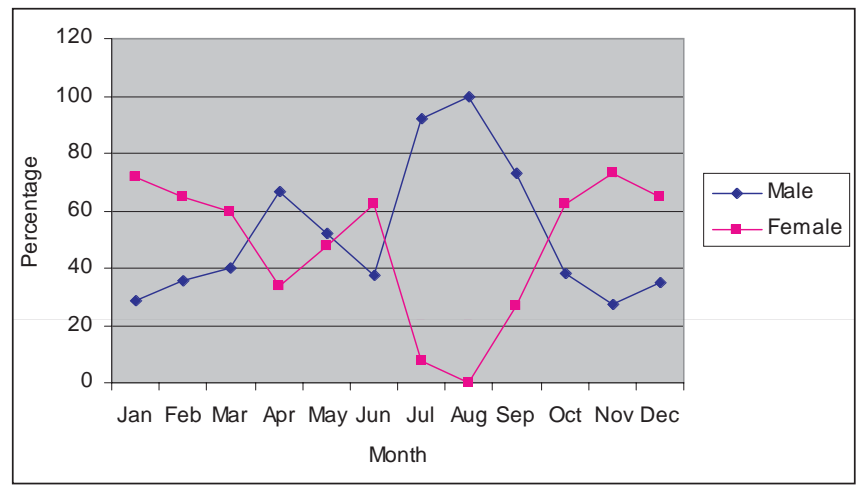

Fig. 7: Monthwise percentage of males and females of chola punti (Puntius chola) sampled from the Kangsa river habitat

\section{Acknowledgements}

The authors are grateful to Professor Md. Ruhul Amin, Principal, Netrakona Govt. College, Netrakona for providing necessary facilities in the Department of Zoology during the course of research work and Md. Farouq Imam, Assistant Professor, Department of Agricultural Statistics, Faculty of Agricultural Economics \& Rural Sociology, Bangladesh Agricultural University, Mymensingh for his active help in statistical analysis.

\section{References}

Doha S. (1974). Investigation into the biology of the gobi Glossogobius giuris (Hamilton-Buchanan) (Percifomes : Gobiidae). Bangladesh J. Zool., 2 (2): 95 -106.

Latifa G. A. and Nahar, L. (1987). Some aspects of biology of Puntius stigma. Bangladesh J. Zool., 15(1): 51-58.

Le Cren E. D. (1951). The length-weight relationship and seasonal cycle in gonad weight and condition in the perch (Perca fluviatilis ). J. Anim. Ecol., 20: 201-219.

Rahman A. K. A. (1989). Freshwater Fishes of Bangladesh. Published by the Zoological Society of Bangladesh 364 pp.

Rahman M. H. (1990). Studies on some aspects of biology of Lepidocephalus guntea (Hamilton) (Cypriniformes : Cobitidae). M. Sc. Thesis, Department of Zoology, Rajshahi University. Rajshahi 128 pp. 
Shafi M. and Quddus M. M. A. (1975). The length-weight and length-girth relationships and condition in the carp Labeo rohita (Hamilton, 1822). Bangladesh J. Sci. \& Ind. Res., $\mathbf{X}(3$ \& 4): 268-273.

Shafi M. and Quddus M. M. A. (2001). Bangladesh Matsho Shampad. Kabir publications. Dhaka.

Simpson G. G., Roe A. and Lewontin R. C. (1960). Quantitative Zoology. Harcourt Brace \& Co., New York, 440 pp.
Snedecor G. W. (1956). Statistical methods. Lowa State University Press, Amer. Lowa, 534 pp.

Srivastava G. J. (1968). Fishes of Eastern Uttar Pradesh. Vishwavidyalaya Prakashan, Varanasi, 163 pp.

Talwar K. and Jhingran A. G. (1991). Inland Fishes, Vol. 1. Oxford \& IBH Publishing Co. Pvt. Ltd., New Delhi110,001, India, 541 pp.

Received : July 05, 2009;

Accepted : February 09, 2010 